\title{
A New Scientific Paradigm of Physical Culture
}

\author{
Vasil Sutula* \\ Doctor of Education, Kharkiv State Academy of Physical Culture, Europe
}

Submission: July 07, 2021; Published: July 16, 2021

*Corresponding author: Vasil Sutula, Doctor of Education, Kharkiv State Academy of Physical Culture, Europe

Abstract

The purpose of the study is to present a new scientific paradigm of physical culture. Research methods: Include an analysis of special literature that covers various aspects of human development exercise activities. The results of the analysis: it is shown that the new scientific paradigm of physical culture is a system of worldviews and concepts about the sphere of human activity related to the use of physical exercises for the name of which in scientific and social practices the term "physical culture" is most often used.

Keywords: Paradigm; Theory; Physical culture; Sport; Physical fitness; Physical education

\section{Introduction}

In his response to S Grant book [1] Malcolm noted that when he became acquainted with the system of special education in the post-Soviet countries, he was struck by the widespread use of the term "physical culture" and the fact that existing notions of physical culture were reduced to traditional sports science and physical education. The remark made by the author reflects the existing vagueness of ideas about physical culture and its structure, which is characteristic not only for the scientific practice of the Soviet Union [1-4] and post-Soviet countries [5,6], but also for English-language scientific practice [7-9]. It is obvious that the unresolved problem, and scientific research in this area has been going on for the third century, requires the formulation of a new scientific paradigm of physical culture. Its essence is as follows. First, it must be recognized that in society there is a special sphere of human activity related (directly or indirectly) to the use of physical exercises, which develops in accordance with the fundamental laws of social development. The term "physical culture" is most often used for its name in modern scientific and social practices $[10,11]$. Second, the social mechanism of human self-development is based on the social laws of "growth of needs" and "relationship of needs and activities." Their action in this area of society is manifested in the dialectical unity, on the one hand, the competing activities of people to meet the various needs for the use of exercise, and on the other hand, the social evaluation of such activities [12]. Third, in the field of human activities related to the use of physical exercises in the second period of modern times began to form three basic trends in its development, depending on which functions of physical exercise (health, development, competition, entertainment) were used more in social practice: a) health and development, which led to the formation in the middle of the $19^{\text {th }}$ century of the social institute of physical education; b) competitive and entertaining, which led to the formation of the social institute of sports c) health and entertainment, which led to the formation in that historical period of the social institute of physical fitness.

Within the generalizing theory [13], which is based on the above scientific paradigm, between the consensus definitions of basic concepts such as "physical culture", "physical education", "sports", "physical fitness" there is subordination. The most general level of knowledge about this area of human activity is accumulated in the concept of "physical culture", which is a historically determined human activity associated (directly or indirectly) with the use of exercise and its individual and socially significant results [14]. From it follow the definition of the basic forms of social manifestation of physical culture, because of concretization of forms of human activity regarding the use of physical exercises. Thus, modern sport, as a special socio-cultural phenomenon, is a historically determined activity of people associated (directly or indirectly) with the use of physical exercises, which aims to prepare and participate in competitions, as well as individual and socially significant results of such activities [15]. Physical education, as a special socio-cultural phenomenon, is a 
historically determined activity of people associated (directly or indirectly) with the use of physical exercises in education, as well as individual and socially significant results of such activities [16]. Physical fitness, as a special socio-cultural phenomenon, is a historically determined activity of people associated (directly or indirectly) with the use of exercise at leisure, as well as individual and socially significant results of such activities $[17,18]$.

\section{References}

1. Grant S (2012) Physical Culture and Sport in Soviet Society: Propaganda, Acculturation, and Transformation in the 1920s and 1930s. New York: Routledge, USA, p. 277.

2. Riordan James (1977) Sport in Soviet society: development of sport and physical education in Russia and the USSR.1977 Cambridge [England]; New York: Cambridge University Press, p. 435.

3. Mike O'Mahony (2007) Sport in the USSR: Physical Culture-Visual Culture. The Slavic and East European Journal 66(3).

4. Robert Edelman (2013) Physical Culture and Sport in Soviet Society: Propaganda, Acculturation and Transformation in the 1920s and 1930s. International Journal of the History of Sport 30(18): 22232223.

5. Theory and methods of physical culture: a textbook for students of higher educational institutions carrying out educational activities in the direction of 521900 "Physical Culture" and specialty 022300 Physical Culture and Sports. In: Yu F Kuramshin (Ed.), ( $4^{\text {th }}$ edn), 463c.

6. Theory and methods of physical education: textbook. for students. higher textbook lock phys. education and sports. In: T Yu. Krutsevich, NE Pangelova, OD Kryvchikova, et al. 2 volume. (2 ${ }^{\text {nd }}$ edn), Reworked. Kyiv: National University of Physical Education and Sport of Ukraine, publishing house, Olympus. l-ra, 2017. - Vol. 1. General bases of the theory and methods of physical education p. 384.
7. Wuest D, Bucher C (1995) Foundations of Physical Education and Sport, Ch. A. Bucher. (12 ${ }^{\text {th }}$ edn), Boston, Burridge, Dubuque: WCB / McGraw-Hill, p. 472.

8. Andrews D, Silk M (2011) Physical Cultural Studies: Engendering a Productive Dialogue. Social Sport J 28: 1-3.

9. Brown DHK (2019) Physical Culture. Societies 9(1): 23.

10. Vasyl Sutula (2016) Physical culture: prerequisites for the theory. Theory and methods of physical education and sports 3: 60-65.

11. Sutula V (2019) Peculiarities of cultural and historical transformation of the concept of physical culture. Slobozhansky scientific and sports bulletin 5(73): 5-13.

12. Vasyl Sutula (2019) Social Mechanism of Self-Development of Physical Culture. Am J Biomed Sci \& Res 2(6).

13. Vasil OS (2018) Problems and Perspectives of Construction of the Generalized Theory of Physical Culture. J Phy Fit Treatment \& Sports 3(4): 555620

14. Sutula VO (2018) Generalizing the Definition of Physical Culture. J Phy Fit Treatment \& Sports 2(3): 555586.

15. Vasil S (2018) General Definition of the Concept Sports. J Phy Fit Treatment \& Sports 4(4): 555644.

16. Vasil Sutula (2017) On the essence of the connection between physical culture and physical education. Theory and methods of physical education and sports 4: 91-96.

17. Vasyl Sutula (2019) Terminological and conceptual problems of cognition of the wellness and recreational direction of development of physical culture of modernity. Slobozhansky Scientific and Sports Bulletin 2(70): 5-12.

18. Vasil Sutula (2016) On the essence of the connection between physical culture, physical recreation and physical fitness. Theory and methods of physical education and sports 4: 77-84.

\section{Your next submission with Juniper Publishers} will reach you the below assets

- Quality Editorial service

- Swift Peer Review

- Reprints availability

- E-prints Service

- Manuscript Podcast for convenient understanding

- Global attainment for your research

- Manuscript accessibility in different formats

( Pdf, E-pub, Full Text, Audio)

- Unceasing customer service

Track the below URL for one-step submission https://juniperpublishers.com/online-submission.php 